DOI: $10.18778 / 2084-140 X .09 .35$

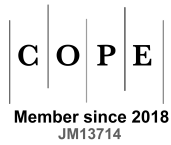

Elwira Kaczyńska (Łódź)

(iD) https://orcid.org/0000-0002-4545-1927

Krzysztof Tomasz Witczak (Łódź)

(iD) https://orcid.org/0000-0001-8895-974X

\title{
The Undying Controversy of the Presence of Slavs on the Island of Crete. Remarks on a New Book by Pantelis Haralampakis
}

$\mathrm{T}$ hree years ago, Pantelis Haralampakis

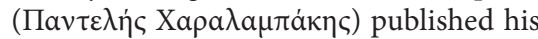

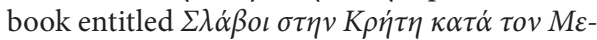

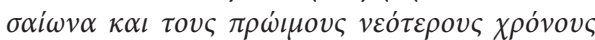

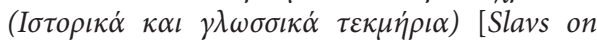
Crete in the Middle Ages and the Early Modern Times (Historical and Linguistic Evidence)], Andy's Publishers, Athens 2016, pp. 340. We intend to discuss not only the contents of the book, but also the conclusions offered by the author and what he managed to accomplish through his work.

The monograph under review (Haralampakis 2016) caps years of studying the issue of the Slavic presence in Crete and Slavic lexical influence on the Cretan dialect of Modern Greek and on the island's toponymy. The work is clearly divided into two parts. First (p. 15-85), the author discusses historical data, from the $7^{\text {th }}$ century up until the Ottoman conquest of the island (between 1645 and 1669). He also looks at research hypotheses concerning the putative presence of the Slavs in Crete, which is suggested by both Greek and foreign scholars. Then (p. 87-238), Mr. Pantelis Haralampakis (henceforth $\mathrm{PH}$ ) presents linguistic evidence, of both lexical (Slavic loans) and onomastic (i.e. Cretan toponyms of supposed Slavic origins) character. The monograph includes (aside from a preface and introduction, p. 5-14) a rather detailed summary (p. 239-251), a Greek translation of Czech traveler Jan Hasišteinskýs 1493 account concerning Crete (p. 253-266), a comprehensive list of reference books (p. 267-290), pictures (p. 291-297), a summary in English (p. 299-305), indexes (p. 307-337), and a table of contents (p. 339-340). Already a look at the book's contents proves that the author devotes twice as much place to linguistic argumentation and documentation as he does to historical data.

The issue of the Slavic presence in Crete has been widely studied by both Greek and foreign scholars ${ }^{1}$. The earliest works discussing the Slavic settlement of Crete were authored by Bulgarian historians ${ }^{2}$. Unfortunately, the medieval

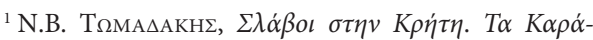

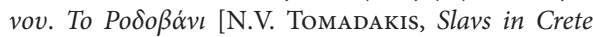
Place-names Karanou. Rodovani], EEK $\Sigma$ 1, 1938, p. 425-431; IDEM, $\Sigma v \mu \beta o \lambda \dot{\eta} \varepsilon\llcorner\varsigma \tau \eta v \mu \varepsilon \lambda \dot{\varepsilon} \tau \eta v \tau \omega v$

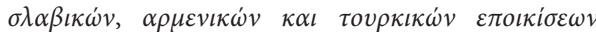

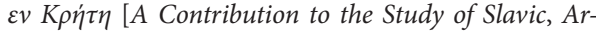
menian and Turkish Settlements in Crete], $\operatorname{EEK} \Sigma 2$,

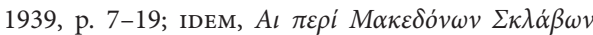

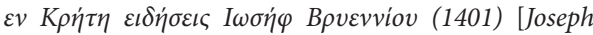
Vryennios' Testimony on Macedonian Slaves in Crete

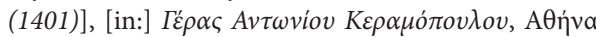
1953, p. 105-111. See also M. VASMER, Die Slaven in Griechenland, Berlin 1941 [repr. Leipzig 1970]; Й. ЗАимов, Заселване на българската Славяни на Балканския полуостров. Проучване на жителските имена в българската топонимия [J. ZAIмоV, Settlement of the Bulgarian Slavs on the Balkan Peninsula. Study of Inhabited Place Names in the Bulgarian Toponymy], София 1967.

${ }^{2}$ И. Шишмановъ, Славянски селища въ Крите и на другите острови [I. ŠIšmanov, Slavic Settlements on Crete and other Islands], БП 4, 3, 1897, p. 2-38; И. САКАЗОВ, Новоодкрити документь отъ края на XIV. вюкъ за булгари оть Македония продавани като роби [I. SAKAZov, New Documents from the End of the $14^{\text {th }}$ Century Referring to Bulgars from Macedonia Sold as Slaves], RMac 7, 2/3, 1932,
} 
period provides little relevant data and essentially each extant source needs to be considered. Usually, the first appearance of the Slavs in Crete is associated with Thomas the Presbyter's account concerning the Slavic invasion of Crete in 623. The original text has survived in Syrian and is quoted below in a literal English translation: The Slavs invaded Crete and the other islands. There some blessed men of Qènneshrē were taken captive and some twenty of them were killed $^{3}$. This information has not been independently verified but this is hardly surprising in the early medieval context. Most historians consider Thomas the Presbyter's account reliable but $\mathrm{PH}$ argues that it contains many inconsistencies. First, no place called Qènneshrē exists in Crete. This name refers to a village in Syria, near the Euphrates, where an early Christian monastery was located. Secondly, if the monks lived is Syria, their death cannot have anything to do with Crete or other Aegean islands. Thirdly, the information has not been independently corroborated, with the $7^{\text {th }}$ century being typically mentioned in the context of Arab raids. What is more, the Arabs were known for plundering monasteries and did not stop short of killing Christian monks. PH suggests that Thomas the Presbyter mistook the Arabs for the Slavs (p. 18-22). The weak part of this argument is a well-known fact that the Arab conquests only started after Mahomet's death (in $632 \mathrm{AD}$ ) and the Byzantine Syria was conquered by the Arabs between 634 and 640. Meanwhile, the Qēnneshrē monks died in 623 in Crete, which at that time was part of the Byzantine Empire. Of course, we may assume that Thomas the Presbyter made a significant mistake dating the events (by a several-year margin), or even that the Qènneshrē monks fled to Crete fearing the Arab terror. However, the chronicler unambiguously identified the killers of the Syrian monks as Slavs, and it is unlikely that a Syrian author should have confused the Arabs and the Slavs. For that reason, the accuracy of Thomas's account is not called into question. His narrative is reliable because it does not focus on the raid

p. 1-62.

${ }^{3}$ A. Palmer, The Seventh Century in the West-Syrian Chronicles, Liverpool 1993, p. 18. itself but rather on the fortunes of twenty Syrian monks captured and killed by the Slavs during the invasion of Crete and the neighboring islands. Thomas does not explain why there were Syrian monks in Crete or whether the Slavs took control of the island or merely raided it. Only the first scenario would justify dating early Slavic settlement in Crete already to the $7^{\text {th }}$ century. There is no independent verification of the Slavic invasion of Crete in 623 and theoretically doubts may be raised as to whether it happened, but there are no grounds for questioning the Slavic attacks on Crete and other islands in the $7^{\text {th }}$ century or the grisly death of Syrian monks at the hands of Slavic attackers.

Most scholars believe that the Slavic settlement of Crete only began in 961. The island was conquered by the Arabs around 824. The Byzantine Empire made a few attempts to regain Crete, but their numerous military operations had failed ${ }^{4}$. It was only in 961 that Nikephoros Phokas, a brilliant Byzantine military commander and a future emperor (between 963 and 969) reconquered Crete and reintegrated it into the Byzantine Empire. Next, in order to secure the island against another Arab invasion, the Byzantine authorities relocated war veterans there. The Byzantine army under the command of Nikephoros Phokas had in its ranks Russian, Bulgarian, and other Slavic mercenaries, so Greek historians believe that the first Slavic settlements in Crete were established after 961, in the form of military camps under the auspices of the Byzantine Empire. After a couple of centuries in the Greek environment, the Slavic inhabitants of these settlements had been completely Hellenized. It is speculated that the Cretan family name Sclavo (Mod. Gr. $\Sigma \kappa \lambda \dot{\beta} \beta$ oc), recorded in Venetian sources, proves the Slavic ancestry of its bearers. PH rejects the hypothesis about the settlement of Slavic veterans in Crete, remarking that Slavic place names in the island are only recorded in Venetian documents from between the $13^{\text {th }}$ and $17^{\text {th }}$ centuries. However, it needs to be noted that the Greek sources from the second Byzantine period (i.e. between 961 and 1204) record only a handful of Cretan

\footnotetext{
${ }^{4}$ T.E. Detorakis, History of Crete, trans. J.C. Davis, Iraklion 1994, p. 126-128.
} 
oeconyms: these are mostly the names of former settlements where the dwellings of Church hierarchs (bishops) were located, rather than new settlements founded by the colonists or war veterans. Elsewhere in his book, $\mathrm{PH}$ discusses later data from the Venetian period (between 1204 and 1669), which mention a South Slavic lineage of some Cretans. Since these particular aspects are not contested, we are not discussing them in this review.

After presenting historical data, $\mathrm{PH}$ proceeds to discuss the Cretan dialectal lexemes of suspected Slavic origin and divides the entire material into four parts:

Group A: appellatives of Slavic origin in the Cretan dialect (p. 89-127): ßépa f. 'covenant, armistice, temporary peace, reconciliation'

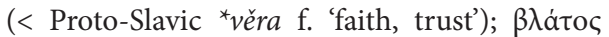
m. 'bog, mud' (< PSl. ${ }^{*}$ bolto n. 'id.); ( $\left.\tau\right) \zeta o v j \mu \pi \varepsilon-$ $\rho$ n. 'a breeding animal, esp. a sheep, goat, cow' (< PSl. * zabrz m. 'bison'); калíkı n. 'kopek; an old Russian coin' (< Russ. копейкa); $\lambda \varepsilon \dot{\varepsilon} \sigma \kappa a \mathrm{f}$. 'a place where wild goats live; a steep place where animals are usually captured';

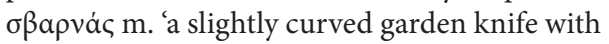
a toothed blade', also oßápva f. 'an agricultural tool for leveling the ploughed surface in the form of a plank with metal teeth; a harrow' (< PSl. ${ }^{*}$ borna f.); $\sigma \kappa \lambda \dot{\varepsilon} \pi \alpha$ f. 'a disease affecting horses'. Therefore, $\mathrm{PH}$ identifies seven certain Slavic loans.

Group B: Cretan appellatives of possible Slavic origin (p. 127-132): кроvбéßa f. 'companionship, company, venture'; $\lambda$ á $\sigma \omega$ 'to shout in order to drive animals to a pen'; $\sigma \tau \alpha \lambda i \zeta \omega$ 'to lead animals to a shadowy place during scorching hot'.

Group C: words erroneously classified as

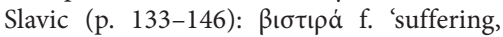
a disease caused by demonic forces'; 〈áka

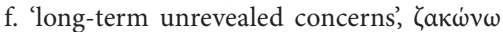
'to worry, to fret, to conceal suffering'; ká$а$ aßo $\mathrm{m}$. 'small stream; canal; sewage drain'; кoбapıá f. 'shepherd's hut income; sheep's pen'; ко́ккораৎ ог ко́ккотаৎ m. 'rooster';

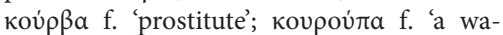

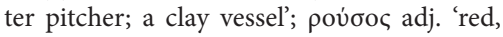

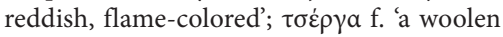
blanket'; $\tau \sigma \varepsilon \rho \gamma \omega \dot{\nu} \omega$ 'to mend sth'.
Group D: Slavic words occurring in Modern

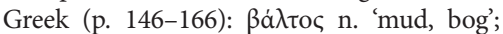

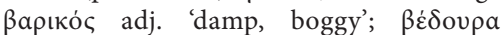
f. 'a wooden basket for milk or sour milk'; $\beta \varepsilon \rho \beta \varepsilon \rho i \tau \sigma \alpha$ f. 'squirrel'; $\beta i$ i $\sigma \alpha \mathrm{f}$. 'stick'; $\beta \lambda \alpha \dot{-}$ $\sigma \alpha \tau a$ n. pl. 'sheep or other long-furred animals'; ßоирко́入акаৎ m. 'a dead man whose body is not decomposing and who raises from the tomb to drink somebody's blood';

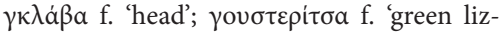
ard, Lacerta viridis Laurenti'; $\gamma \rho \alpha v i \tau \sigma \alpha$ f. 'downy oak, Quercus pubescens Willd.'; $\delta$ ó $\mu \pi \rho \circ$ or $v \tau$ tó $\mu \pi \rho \circ \varsigma$ adj. 'honest, reliable';

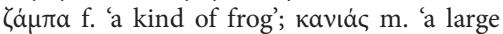
bird of prey'; $(\gamma) \kappa \lambda i \tau \sigma \alpha$ f. 'shepherd's crook';

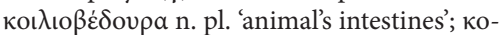
$\kappa(\kappa)$ o $\rho \dot{\tau} \tau$ เ n. 'pistachio, Pistacia terebinthus

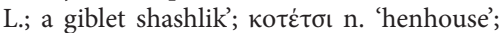
$\lambda \alpha \gamma \kappa \alpha \dot{\delta} \mathrm{ı}$ n. 'valley, gorge'; $\lambda$ o $\mu \pi \mathrm{o} \delta$ เá f. 'dit$\operatorname{tany} ; \mu \pi \varepsilon \dot{\varepsilon} \mu \pi \varepsilon \lambda \eta \mathrm{f}$. 'measles'; $\mu \alpha \rho \kappa \alpha ́ \lambda \alpha \mathrm{f}$. 'the period of sheep's copulation'; $\mu$ ó $\rho$ a f. 'a mare;

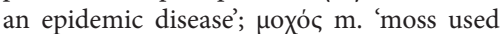
for starting a fire'; $\mu \pi i \sigma \tau \rho o \varsigma$ adj. 'hawkeyed; clever'; $\pi \dot{\varepsilon} \sigma \tau \rho \circ \varphi \alpha$ f. 'trout'; $\pi i \sigma \tau \rho \circ \varsigma$ adj. 'mottled, spotted (of a hen)'; pajá $\mathrm{n}$. 'a species of grass with a spike-like inflorescence, Imperata cylindrica Beauvois';

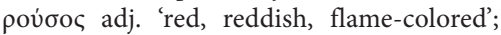

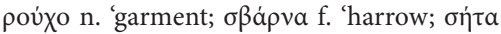
f. 'flour sieve'; $\sigma \tau \operatorname{cou} \mu \pi i \zeta \omega$ 'to smash with

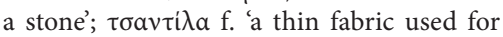
filtering milk; a pouch for filtering curd';

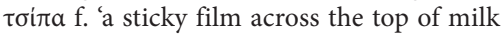

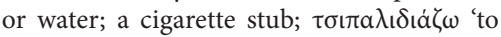
create a film across the top of milk'.

The author's division of the lexemes into particular groups is mostly clear although assigning some of the words to groups A and $\mathrm{D}$ may be questioned. For example, the word $\sigma \kappa \lambda \varepsilon \dot{\varepsilon} \pi \alpha$, which is presently unknown in the island but is attested in the Cretan epigraphy between $13^{\text {th }}$ and $15^{\text {th }}$ centuries, was - according to $\mathrm{PH}$ - once used in other regions of Greece (including North Macedonia, Laconia, and Arcadia). A question thus arises as to why $\mathrm{PH}$ classified this word as a Cretan dialectal vocabulary item (group A). It is additionally worth noting that the word $\sigma \kappa \lambda \dot{\varepsilon} \pi \alpha$ is attested in the Byzantine Hippiatrica ${ }^{5}$, and also in the modern

\footnotetext{
${ }^{5}$ Corpus Hippiatricorum Graecorum, vol. II, Hippiatrica Parisina Cantabrigiensia Londinensia Lugdunensia, Appendix, ed. E. Oder, C. Hoppe, Lipsiae 1927, p. $289,298$.
} 
period in the sense of 'Aussatz / leprosy' in Arcadia, and in the sense of 'Kopfgrind / dermatophytosis' in the Pontic area (Trabzon) ${ }^{6}$. In the previous centuries, the word $\beta \dot{\varepsilon} \rho \alpha$ was known not only in Crete but also in other regions of Greece (Chios, Euboea, Skopelos) 7 . What is more, we cannot agree with Max Vasmer and $\mathrm{PH}$, who claim that the Cretan word $\beta \dot{\varepsilon} \rho \alpha$ f. 'covenant, armistice, temporary peace, reconciliation' represents a South Slavic borrowing. It is worth noting that in his monumental work on the Arkadi monastery Timotheos Veneris, the metropolitan bishop of Crete between 1934 and 1941, explained the rare word $\beta \varepsilon \dot{\varepsilon} \rho \alpha$ used in a Cretan folk song from the end of the $19^{\text {th }}$ century and correctly pointed to its Ottoman

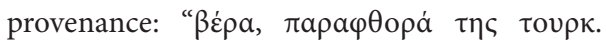
$\lambda \dot{\varepsilon} \xi \varepsilon \omega \varsigma \beta \varepsilon \rho \dot{\varepsilon}=$ To $\pi \alpha \rho \alpha \delta i \delta \varepsilon \sigma \theta \alpha \mathrm{l}, \pi \alpha \rho \alpha \dot{\delta} \delta \sigma \iota \varsigma$.

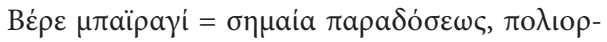
$\kappa o u \mu \varepsilon \dot{v} \omega v$ " [ $[\beta \varepsilon \dot{\varepsilon} \alpha$, a corruption of the Turkish word vère = capitulation, surrender. Vèrebayraği = flag of surrender (of besieged people) $]^{8}$. Also Romanian veră 'capitulation' is a borrowing from Turkish vère 'capitulation, surrender'. In short, we maintain our stance from 11 years ago, namely that Slavic influence on Cretan

\footnotetext{
${ }^{6}$ G. MeYer, Etymologisches Wörterbuch der albanesischen Sprache, Strassburg 1891, p. 125. The appellative $\sigma \kappa \lambda \dot{\varepsilon} \pi \alpha$ f. 'lichen, dermatophytosis of the head, fester-

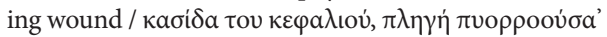
is still used in the Pontic dialect of Modern Greek, see on-line: http://www.pontos-news.gr/lexicon/words/ $\sigma \kappa \lambda \dot{\varepsilon} \pi \alpha[12$ V 2019].

${ }^{7}$ E. KACZyŃsKA, Rozważania o domniemanym slawizmie $w$ dialekcie kreteńskim języka nowogreckiego [Considerations on an Alleged Slavism in the Cretan Dialect of Modern Greek], RHu 64, 6, 2016, p. 31-50.

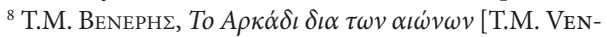
ERIS, The Arkadi Monastery through the Ages], A $\theta$ inva 1938 , p. 352, fn. 3. See also Г.Е. Апогто Аакнг, А $\rho-$

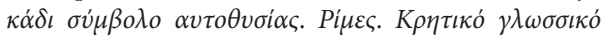
$\iota \delta i \omega \mu \alpha$ [G.E. ApostolakIs, Arkadi - a Symbol of Self-

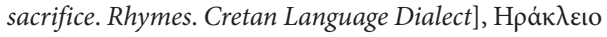
2014, p. 116.

${ }^{9}$ H.F. Wendt, Die türkischen Elemente im Rumänischen, Berlin 1960, p. 120. See additionally H.C. HonY, F. Iz, A Turkish-English Dictionary, Oxford 1947, p. 368 (s.v. vère).
}

dialectal vocabulary is rather weak and concerns approx. 30 appellatives ${ }^{10}$.

Slavic supra-regional loans into Greek should be widely-known in Crete. Meanwhile, the word $\tau \sigma \alpha v \tau i \lambda \alpha$ f. 'a thin fabric used for filtering milk' is only attested in the island in the Apokoronas eparchy ${ }^{11}$. In the other parts of the

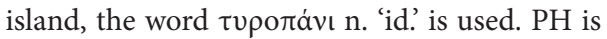
critical of the set of Slavic loans attested in Cretan speech which we suggested and sometimes questions whether some of the terms are in use in Crete. For example, he claims that he has never heard a native Cretan use the word $\gamma \kappa \lambda \dot{\alpha} \beta a$ $\mathrm{f}$. ' $a$ head', adding that no dictionary of the Cretan dialect has recorded this word (p. 152). However, a different opinion was expressed by Eustathios Petrulakis (from the Cretan town of Rhethymno), who at the beginning of the $20^{\text {th }}$ century (before 1905) confirmed beyond all doubt that this word was used in Crete ${ }^{12}$. $\mathrm{PH}$ writes that the phytonym $\gamma \rho \alpha v i \tau \sigma \alpha$ f. 'downy oak, Quercus pubescens Willd.' has not been

${ }^{10}$ E. KaCzyŃsKa, K.T. WitcZaK, Elementy słowiańskie w leksyce kreteńskiej [Slavic Elements in the Cretan Vocabulary], RKJŁTN 53, 2008, p. 129-146.

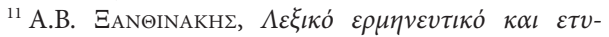

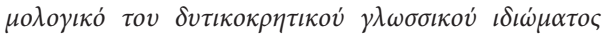
[A.V. Xanthinakis, Explanatory and Etymological Dictionary of the West Cretan Dialect], ${ }^{4}$ Iraklion 2009, p. 667. This loan comes, without a doubt, from South Slavic languages, cf. OCS. изодило n. 'an appliance for filtering', Bg. dial. цедило 'a filter; a thin fabric for filtering', also 'a woolen sheet for carrying children', Мас. иедило 'an appliance for filtering milk and other liquids', also 'a sheet for covering loaves on a board', Sloven. cedilo 'a sieve, a vessel for filtering', SCr. cjèdilo n. 'an appliance for filtering water, milk, wine' < PSI. *cědidlo n. 'an appliance for filtering liquids; a piece of fabric for filtering milk', cf. Pol. cedzidło 'an appliance for filtering, a filter').

${ }^{12}$ P. Kretschmer, Der heutige lesbische Dialekt verglichen mit den übrigen nordgriechischen Mundarten, Wien 1905, p. 434. Then, W. BudziszewskA, Zapożyczenia słowiańskie $w$ dialektach nowogreckich [Slavic Borrowings in the Modern Greek Dialects], Warszawa 1991, p. 16, writes (without stating a reference) that in the Cretan province of Chania the phrase $\dot{\varepsilon} \chi \varepsilon$ เ $\sigma \kappa \lambda \eta \rho \eta \dot{~} \gamma \kappa \lambda \alpha \dot{\beta} \alpha$ 'you have a hard head (= you are stubborn)' is used. 
recorded in any dictionary of the Cretan dialect. However, already German botanist Theodor von Heldreich (1822-1902) and his student Spirydon Miliarakis (1852-1919) pointed out that in the $19^{\text {th }}$ century and at the beginning of the $20^{\text {th }}$ century this term was not yet supra-regional and only occurred in Crete, Attica, and Phocis (Parnassos) ${ }^{13}$. The explanation for this may be two-fold. Firstly, some words lose their previous productivity, give way to their synonyms, and gradually fall out of use. Secondly, the authors of dialectal dictionaries do not include those words which - in their opinion - come from the Modern Greek koine. For that reason, the dictionaries of the Cretan dialect do not include the word $\beta \varepsilon \rho \beta \varepsilon \rho i \tau \sigma \alpha$ f. 'a squirrel' (this animal does not live in Crete) although the Cretans know this word and commonly use it. Any Cretan child will easily recognize and name a squirrel, just as they will a fox, a lion, a bear, and a giraffe, although these animals do not live in Crete either. PH emphasizes (p. 89) that the word ßépa f. 'an engagement ring' (which was at one point borrowed from the Venetian dialect of Italian) is commonly used in Crete, and it may be quickly verified that most authors of dictionaries of the Cretan dialect leave out this word on purpose, erroneously assuming that this is not an original dialectal term but a loan from the Modern Greek koine. PH also casts doubt on the purely Cretan character of the words

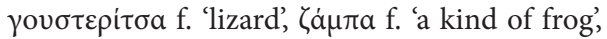
and kaviác m. 'some bird of prey (a kite?)', even though 40 years ago Eleutherios Platakis, a native Cretan, included these words on his list of Cretan names of animals ${ }^{14}$.

In the third part of the monograph (p. 167-238), PH discusses the Cretan place

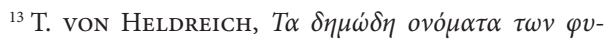
$\tau \dot{\omega} v$ [The Folk Names of Plants], $2^{\text {nd }}$ ed. prepared by S. Miliarakis, AӨj́va 1919 [repr. 2011], p. 109. See also W. BudzIszewska, Zapożyczenia..., p. 18.

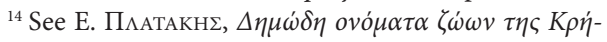
$\tau \eta \varsigma$ [E. Platakis, Folk Names of Animals of Crete],

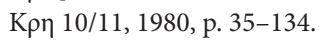

names of Slavic origin, dividing the onomastic material into three parts:

Group A: Cretan toponyms and micro-toponyms of Slavic provenance (p. 167-186):

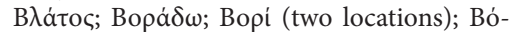

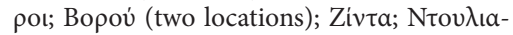

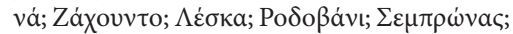

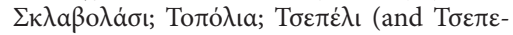
$\lambda \alpha \dot{\kappa ı) ; ~ Х а \rho ß a ́ \tau a . ~}$

Group B: Cretan (micro-)toponyms of likely Slavic provenance (p. 186-213): Акарá-

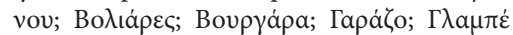

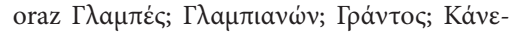

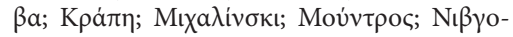

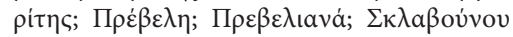

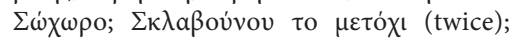

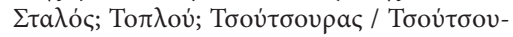


Group C: Cretan (micro-)toponyms erroneously classified as Slavic or Greek place names containing Slavic elements

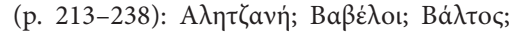

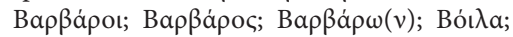
Bou $\lambda \gamma \alpha \dot{\alpha} \omega(v)$ (two toponyms); Гaßpavoú;

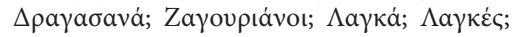

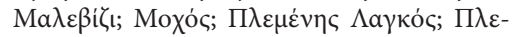

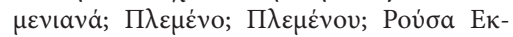

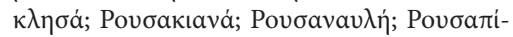

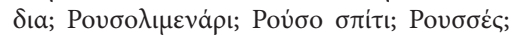

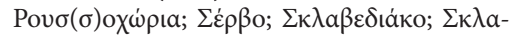

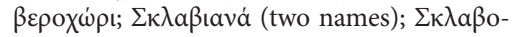

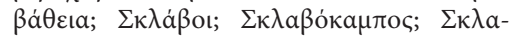

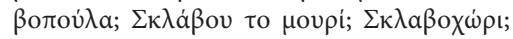

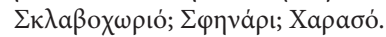

It is surprising that in the third part of the monograph $\mathrm{PH}$ does not make even a single reference to the two-volume work on Modern Greek oeconymy by Haralampos Symeonidis, an eminent Greek expert on linguistics and onomastics ${ }^{15}$. What is more, $\mathrm{PH}$ does not list this monumental dictionary in his bibliography. In order to present the great complexity of the research problem, we quote Symeonidis's

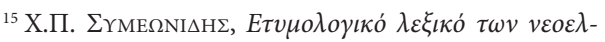
$\lambda \eta v \iota \kappa \omega v$ oı $\omega v v \mu i \omega v$ [H.P. SyMEONIDIS, Etymological Dictionary of the Modern Greek Place-names], vol. I-II,

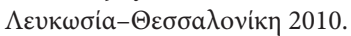


opinions concerning selected Cretan oeconyms which - according to PH's opinion - are of Slavic provenance.

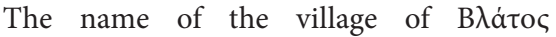
(Kissamos, Chania), which appears in Venetian sources as Vlatos $(1583 ; 1630)$ is - according to Symeonidis ${ }^{16}$ - inspired by the Cretan dialectal appellative $\beta \lambda \alpha \dot{\tau} \tau o \varsigma \mathrm{n}$. 'a muddy place' (whose genesis is identical to that of Mod. Gr. $\beta a \dot{\lambda} \lambda$ to n. or $\beta \dot{\alpha} \lambda \tau_{0} \varsigma$ n. 'id.). Symeonidis postulates purely Greek origins of this oeconym, while $\mathrm{PH}$ argues in favor of its Slavic provenance (p. 167). We tend to agree that the Cretan appellative $\beta \lambda$ átoc, on which the place name is based, is an old Slavic loan, but this fact by no means proves that the village was originally a Slavic settlement.

There are two Cretan oeconyms Bopi ([1] Kissamos, Chania; [2] Sitia, Lasithi). The former was recorded in the Venetian period (1583) and the latter in the $19^{\text {th }}$ century (Vuriá 1834 ; Bopi 1881). PH argues in favor of the Slavic origins of both (p. 168-171). Symeonidis, on the other hand, believes that the place name derives from the Greek appellative ${ }^{\star} \beta o \rho i$, a diminutive of Mod. Gr. ßopóc m. 'a room for animals' $(<\text { PSl. oborb })^{17}$. In his opinion, the origins of the village are purely Greek, although the appellative serving as the basis is a South-Slavic loan. Symeonidis also quotes N.G. Katapotis, who claims that the place name comes from the family name ${ }^{\star}$ Bopńc. We are of the opinion that the Cretan place name Bopi appeared in the course of inflectional derivation ( to Bopi).

The oeconym Zivta (Monofatsiou, Iraklion) appears in Venetian sources as Sinda (1380), Sida (1583), Sinda (1630), and in Turkish documents as Zide (1671), Zidá (1834). Symeonidis, invoking K. Amantos, suspects that the Cretan place name is the continuation of the Doric name ${ }^{\star} \Sigma i \delta \bar{\alpha}$, cf. Old Gr. $\sigma i \delta \eta$ f. 'a tree or fruit of pomegranate, Punica granatum L. ${ }^{18}$. He also quotes a contrasting opinion of S. Xanthudidis, who claims that the oeconym comes from the Venetian family name Zinta,

\footnotetext{
${ }^{16}$ Ibidem, vol. I, p. 363.

${ }^{17}$ Ibidem, vol. I, p. 371.

${ }^{18}$ Ibidem, vol. I, p. 549.
}

which was attested in Cretan sources in 1475 (Alexandro Zinta). The family-name provenance of the place name seems more probable. $\mathrm{PH}$ advocates the Slavic hypothesis, linking the Cretan place name with the Polish family name of Zynda or Żynda (p. 171).

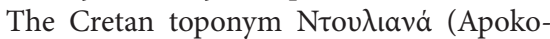
ronou, Chania) is only recorded in historical sources in the $19^{\text {th }}$ century (Dulianá $1834, \Delta$ ov-

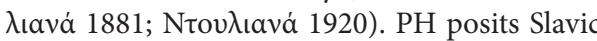
origins of the proper name in question, which - in his opinion - apparently comes from PSl. * dolo m. 'a hole, a concavity or a dug-up pit; a ditch; a moat; a nether area surrounded by hills, a valley' (p. 172-173). According to Symeonidis, the provenance of the place name is unclear ${ }^{19}$. $\mathrm{He}$ also refers to the argumentation of Zaimov ${ }^{20}$ who claims that the Cretan village got its name from Slavic ${ }^{\star}$ Duljane or ${ }^{\star}$ Duljana (cf. the Bulgarian toponym Дияяна), derived from some South-Slavic appellative, cf. SCr. dial. dülo, dúlo n. 'a pipe in the bellows through which you blow to induce fire; a cave in the ground out of which a stream flows; a large concavity, a cave in the ground; the bottom of a wooden vessel', Bg. дуло a pipe for watering a garden; a large opening of a pitcher', also 'the muzzle of a firearm' (<PS1. ${ }^{\star} d u d l o$ n. 'a hole, an outlet, a pipe'). Zaimov and Symeonidis compare the Cretan toponym with the name of the Albanian village of Dulyani, which is of Slavic provenance. Symeonidis's doubts about the validity of Zaimov's hypothesis appear well-founded. In Crete, there is a high number of oeconyms ending in -ıavá (n. pl.). All such items are derived from a proper name and exhibit the possessive meaning, indicating somebody's property. Theoretically, the name could come from a Slavic first name, cf. the Old Russian personal name Дуло $\left(15^{\text {th }}-16^{\text {th }} \mathrm{c}\right.$.), but it needs to be noted that Greek has recorded nu-

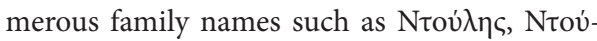

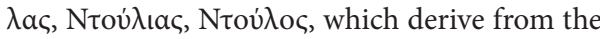
Turkish word $d u l$ 'a widow, a widower ${ }^{21}$. What

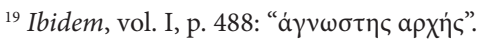

${ }^{20}$ Й. ЗАимов, Заселване..., p. 129.

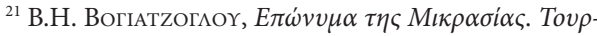

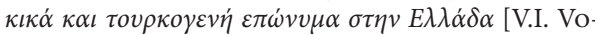
giatzoglou, Surnames of Asia Minor. Ottoman and Turkish-like surnames in Greece], AӨńva 1992, p. 77.
} 
is more, appearing in Crete is also the fami-

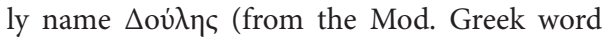

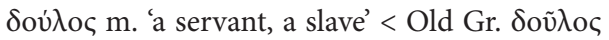
m. 'id.'), already attested in the Venetian period (1390) in the town of Peuko (Viannos, Iraklion) ${ }^{22}$. Consequently, it is problematic to argue in favor of the Slavic provenance of the Cretan

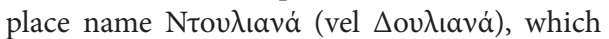
is more easily traceable to a Greek possessive form, indicating a property of a man named

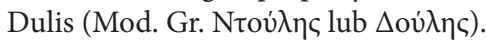

Discussing the place name $\Sigma \varepsilon \mu \pi \rho \dot{\omega} v a \varsigma$ (Kydonia, Chania), already attested in the $17^{\text {th }}$ century (Sembrona 1577), Symeonidis refers to Mod. Gr. $\sigma \varepsilon \dot{\varepsilon} \mu \pi \rho \varsigma$ 'a peasant who as part of neighborhood assistance cultivates somebody else's land' ( $\leftarrow$ South Slavic * sębrz), cf. SCr. (since $14^{\text {th }}$ century) sember 'a farmer, a peasant, a person of low status', Sloven. seber 'id., BRuss. sjabr 'a neighbor' ${ }^{23}$. He does not explain if he considers the morpheme - $\omega$ vac to be a Greek derivational suffix or a South Slavic loan. $\mathrm{PH}$ is in favor of the latter option, classifying this name as purely Slavic (p. 177-179). On the other hand, Hrisoula Tsikritsi-Katsianaki argues that the oeconym $\Sigma \varepsilon \mu \pi \rho \omega$ vac comes from the Greek family name $\sum \dot{\varepsilon} \mu \pi \rho \varsigma^{24}$.

Symeonidis does not discuss the micro-toponym $\Sigma \kappa \lambda \alpha \beta$ o $\lambda$ á Cretan oeconyms including the $\Sigma \kappa \lambda \alpha \beta$ o- element, providing a comprehensive overview of various theories ${ }^{25}$. Most scholars believe that

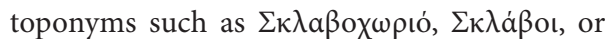

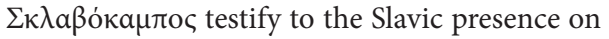
the island, or the presence of Greek inhabitants bearing the family name $\Sigma \kappa \lambda \dot{\alpha} \beta$ oc. $\mathrm{PH}$ is right to reject the Slavic provenance of Cretan toponyms with the initial $\Sigma \kappa \lambda \alpha \beta$ o- element, although at the same time he is of the opinion that the suf-

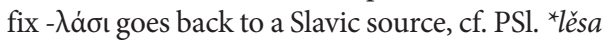
f. 'a wicker of twigs, a bar, a wicker fence, a fence'

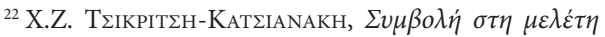

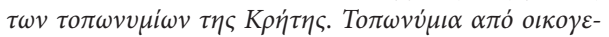

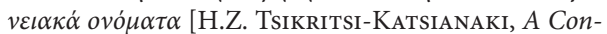
tribution to Studying Toponyms of Crete. Toponyms Derived from Surnames], A 6, 22-23, 1975, p. 50.

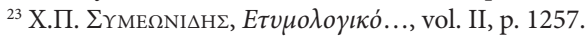

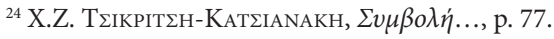

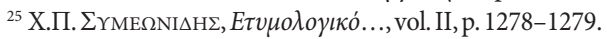

(p. 179-180). However, there is no doubt that the Cretan name $\Sigma \kappa \lambda \alpha \beta$ od $\alpha$ or arose in the Hellenic context and was not borrowed from the old Slavic inhabitants of the island. Symeonidis points to an older meaning of Middle Greek

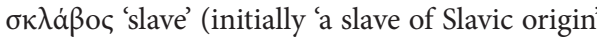
< 'a Slav'). He also quotes K. Amantos's isolat-

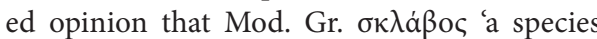
of grapevine or grape (of light yellow color)' is the base for the Cretan toponyms.

The oeconym Toтó $\lambda_{\iota} \alpha$ (Kissamos, Chania), attested in Venetian sources as Topolia (1577), Topogla $(1583,1630)$, is usually traced back

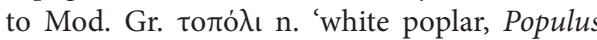
alba L.' (< PSl. ${ }^{\star}$ topolb f. 'id.'). PH advocates the Slavic origins of this Cretan place name (p. 180-181), in line with other scholars ${ }^{26}$. Symeonidis postulates purely Greek origins

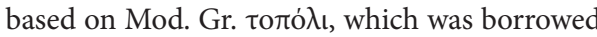
from a Slavic source. However, modern dictionaries of the Cretan dialect do not record

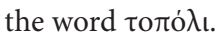

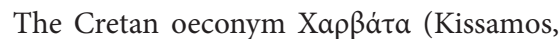
Chania), first attested in 1920, was mentioned

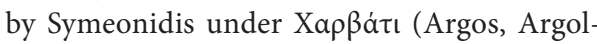

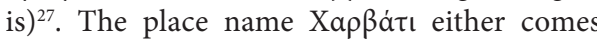
from the ethnic name of the Croats (PSl. ${ }^{*} \mathrm{Chr}$ vati, Cr. Hrvati), or from the Greek name Xa $\rho$ ßátnৎ (lit. 'a Croat'). In the former scenario, the place name would indicate Slavic settlement in Crete (which $\mathrm{PH}$ agrees with), while in the latter this would not be as certain. A late attestation of the oeconym (1920) seems to suggest the

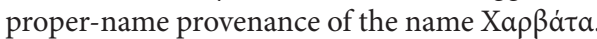

A quick overview of select Cretan toponyms which $\mathrm{PH}$ classifies as purely Slavic demonstrates that the issue of Slavic influence on the toponymy and micro-toponymy of Crete is complex. H. Symeonidis, the author of an

\footnotetext{
${ }^{26}$ И. Шишмановъ, Славянски..., р. 90; N.В. ТямА$\triangle \mathrm{AKH} \Sigma, \Sigma v \mu \beta 0 \lambda \eta \dot{. . ., ~ p . ~ 10 ; ~ M . ~ V A S M E R, ~ D i e ~ S l a v e n . . ., ~}$

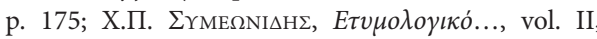
p. 1351-1352. It is worth emphasizing that Max Vasmer prefers a derivation of the Modern Greek place-name Toтó $ı$ ı (n. pl.) from the Common Slavic collective formation ${ }^{*}$ Topolvje 'a collection of poplars; a poplar forest; a place overgrown with poplars / Pappelort'.

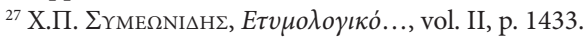


etymological dictionary of Greek oeconyms, favors alternative explanations of many Cretan place names.

The monograph under review is valuable in that $\mathrm{PH}$ presents the current state of research on the issue of the Slavic settlement of Crete and usually (though not always) sides with other Greek scholars. A number of issues is still open to debate. The chronology of the appearance of the first Slavic settlers in Crete is coming under much scrutiny and researchers are divided on this topic (the beginnings of the Slavic settlement are dated either to the $7^{\text {th }}$ century, $10^{\text {th }}$ century, or the beginning of the Venetian rule of the island, i.e. $13^{\text {th }}-15^{\text {th }}$ centuries). Also, the exact number of Slavic loans into the Cretan dialect is debatable. Overall, $\mathrm{PH}$ discusses 57 lexemes and decidedly rejects 12 of them. While some of the author's propositions are not convincing, there can be no doubt that the monograph under review is a substantial and stimulating contribution to studies of the Cretan dialectal vocabulary and the toponymy of Crete.

\section{Translated by Maciej Grabski}

\section{BibliOgRAPHY}

Apostolakēs G.E., Arkadi symvolo autothysias. Rimes, Krētiko glōssiko idiōma, Ērakleio 2014.

Budziszewska W., Zapożyczenia słowiańskie $w$ dialektach nowogreckich, Warszawa 1991.

Corpus Hippiatricorum Graecorum, vol. II, Hippiatrica Parisina Cantabrigiensia Londinensia Lugdunensia, Appendix, ed. E. Oder, C. Hoppe, Lipsiae 1927.

Detorakis T.E., History of Crete, trans. J.C. Davis, Iraklion 1994.

Haralampakis P., Slavoi stēn Krētē kata ton Mesaiōna kai tous prōimous neoterous chronous (istorika kai glōssika tekmēria, Athēna 2016.

Heldreich T. von, Ta dēmōdē onomata tōn fytōn, $2^{\text {nd }}$ ed. prepared by S. Miliarakis, Athēna 1919 [repr. 2011].

Hony H.C., Iz F., A Turkish-English Dictionary, Oxford 1947.
KACZYŃska E., Rozważania o domniemanym slawizmie $w$ dialekcie kreteńskim języka nowogreckiego, "Roczniki Humanistyczne" 64, 6, 2016, p. 31-50.

KACZyŃsKa E., WitcZAK K.T., Elementy słowiańskie $w$ leksyce kreteńskiej, "Rozprawy Komisji Językowej ŁTN” 53, 2008, p. 129-146.

Kretschmer P., Der heutige lesbische Dialekt verglichen mit den übrigen nordgriechischen Mundarten, Wien 1905.

Meyer G., Etymologisches Wörterbuch der albanesischen Sprache, Strassburg 1891.

Palmer A., The Seventh Century in the West-Syrian Chronicles, Liverpool 1993.

Platakēs E., Dēmōdē onomata zōōn tēs Krētēs,

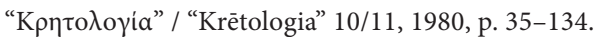

SAKAzov I., Novoodkriti dokumenty ot kraja na XIV. věk za bulgari ot Makedonija prodavani kato robi, "Revue Macédonienne" 7, 2-3, 1932, p. 1-62.

ŠIšmanov I., Slavjanski selišta $v$ Krite $i$ na drugite ostrovi, “Български Преглед”/ “Bălgarski Pregled” 4, 3, 1897, p. 90-126.

Symeōnidēs H.P., Etymologiko lexiko tōn neoellēnikōn oikōnymiōn, vol. I-II, Leukōsia-Thessalonikē 2010.

Tōmadakēs N.V., Ai peri Makedonōn Sklávōn en Krètēe eidēseis Iōsēf Vryenniou (1401), [in:] Geras Antōniou Keramopoulou, Athēna 1953, p. 105-111.

Tōmadakēs N.V., Slavoi stēn Krētē. Ta Karanou.

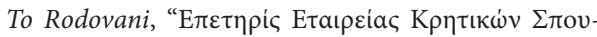
$\delta \omega \dot{v}$ " / "Epetēris Etaireias Krētikōn Spoudōn” 1, 1938, p. 425-431.

Tōmadakēs N.V., Symvolē eis tēn meletēn tōn slavikōn, armenikōn kai tourkikōn epoikiseōn en Krētē,

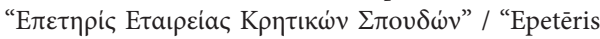
Etaireias Krētikōn Spoudōn” 2, 1939, p. 7-19.

Tsikritsē-Katsianakē H.Z., Symvolē stē meletē tōn topōnymiōn tēs Krētēs. Topōnymia apo oikogeneiaka

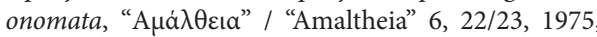
p. 25-98.

Vasmer M., Die Slaven in Griechenland, Berlin 1941 [repr. Leipzig 1970].

Venerēs T.M., To Arkadi dia tōn aiōnōn, Athēna 1938.

Vogiatzoglou V.I., Epōnyma tēs Mikrasias. Tourkika kai tourkogenē epōnyma stēn Ellada, Athēna 1992.

Wendt H.F., Die türkischen Elemente im Rumänischen, Berlin 1960. 
Xanthinakēs A.V., Lexiko ermēneutikó kai etymologiko tou dytikokrētikou glōssikou idiōmatos, ${ }^{4}$ Iraklion 2009.

ZAImov J., Zaselvane na bŭlgarskata Slavjani na Balkanskija poluostrov. Proučvane na žitelskite imena $v$ bălgarskata toponimija, Sofija 1967.

http://www.pontos-news.gr/lexicon/words/ $\sigma \kappa \lambda \dot{\varepsilon} \pi \alpha$ [12 V 2019].

\footnotetext{
Abstract. The paper demonstrates the current state of research on the presence of Slavs on the island of Crete in the Middle Ages, as well as in the modern times. The basis for the discussion is a new book of Pantelis Haralampakis, published in 2016. There are numerous controversies surrounding the issues of the exact chronology of Slavic presence on the island, the lexical influence of South Slavic languages on the Cretan dialect of Modern Greek, as well as possible traces of Slavic settlements in the Cretan toponymy.
}

Keywords: borrowings, Crete, onomastics, place names, Slavic, vocabulary

Elwira Kaczyńska

University of Lodz

Faculty of Philology

Chair of Classical Philology

ul. Pomorska 171/173

90-236 Łodź, Poland

elwira.kaczynska@uni.lodz.pl

Krzysztof Tomasz Witczak

University of Lodz

Faculty of Philology

Chair of Classical Philology

ul. Pomorska 171/173

90-236 Łodź, Poland

krzysztof.witczak@uni.lodz.pl 